\title{
Does Telephone Consultancy Reduce Intensity in the Emergencies? Viewpoints of the Primary Healthcare Workers
}

\author{
Telefon Danışmanlığı Acillerdeki Yoğunluğu Azaltır Mı? Birinci Basamak \\ Sağlık Çalışanlarının Bakış Açıları
}

Özgür ERDEM*', Fatma ÖZDEMIR ${ }^{2}$

\begin{abstract}
Aim: The aim of this research is to examine the viewpoints of the primary health care workers in Turkey regarding directing the patients to the emergency service by providing them with telephone consultancy (TC). Methods: In this cross-sectional study, the universe of the research is composed of the primary health care workers in Turkey. The online questionnaire technique was used to obtain the data. SPSS 15.0 statistical package was used in data analysis and $\mathrm{p}<0.05$ is considered significant. Results: 1083 healthcare worker participated in the study. The proposal of "I support the TC project" is a statistically significant difference in terms of profession, and it was found out that family health employees looked more positively at this project than the doctors $(\mathrm{p}=0,028)$. The total proportion of the health professionals supporting the project was found out to be as low as $17.4 \%$. A statistically significant difference was determined between ages $(\mathrm{p}=0,005)$, gender $(\mathrm{p}=0,005)$, profession $(\mathrm{p}=0,000)$ and years of professional experience $(\mathrm{p}=0,000)$ with the proposal of "TC is a populist approach". The proposal of "TC service reduces the intensity in the emergency service" in term of the profession, the statistical difference was found significant $(\mathrm{p}=0,023)$. Compared with family health employees; it was determined that the physicians did not think TC would reduce urgent applications. Conclusion: In Turkey, the primary healthcare workers mostly oppose the TC issue. As the professional experience increase, this rate increases much more.
\end{abstract}

Keywords: Telephone consultancy, family medicine, emergency service, Turkey

\section{ÖZET}

Giriş: Bu araştırmanın amacı, Türkiye'de aile hekimliği çalışanlarının hastalara telefon danışmanlığı (TD) hizmeti vererek acil servise yönlendirme konusundaki bakış açılarını incelemektir. Yöntem: Kesitsel tipteki bu çalışmada, araştırmanın evrenini Türkiye'de birinci basamak sağlık çalışanları oluşturmaktadır. Verilerin elde edilmesinde online anket tekniği kullanılmıştır. İstatistiksel analizde SPSS.15.0 paket programı kullanıldı ve $\mathrm{p}<0.05$ istatistiksel olarak anlamlı kabul edildi. Bulgular: Çalışmaya 1083 sağlık çalışanı katıldı. "TD projesini destekliyorum" önermesi meslek açısından istatistiksel olarak anlamlı olup; aile sağlığı elemanlarının hekimlere göre bu projeye daha olumlu baktığı tespit edildi ( $\mathrm{p}=0,028)$. Projeyi destekleyen sağlık profesyonellerinin toplam oranı \%17.4 olarak düşük tespit edilmiştir. "TD popülist bir yaklaşımdır" önermesi ile yaş $(p=0,005)$, cinsiyet $(p=0,005)$, meslek $(p=0,000)$ ve mesleki deneyim yılı $(p=0,000)$ arasında istatistiksel olarak anlamlı bir fark saptand. "TD hizmeti vermek acil servisteki yoğunluğu azaltır" önermesi ile meslek açısından istatistiksel fark anlamlı bulundu ( $\mathrm{p}=0,023)$. Hekimler aile sağlığı elemanları ile karşılaştırıldığında TD'nin acil başvurularını azaltacağını düşünmediği tespit edildi. Sonuç: Türkiye'de aile hekimliği çalışanları TD konusuna büyük oranda karşı çıkmaktadır. Mesleki deneyim arttıkça bu oran da artmaktadır.

Anahtar Kelimeler: Telefon danışmanlığı, aile hekimliği, acil servis, Türkiye

Received / Geliş tarihi: 24.02.2018, Accepted / Kabul tarihi: 06.05.2018

${ }^{1}$ Lice Halis Toprak Vakfi Devlet Hastanesi

${ }^{2}$ Diyarbakır İl Sağlık Müdürlüğü

*Address for Correspondence / Yazışma Adresi: Özgür ERDEM. Lice Halis Toprak Vakfi Devlet Hastanesi, Diyarbakır-TÜRKIYE, E-mail: dr.oerdem@hotmail.com

Erdem and Özdemir. Does Telephone Consultancy Reduce Intensity in the Emergencies? Viewpoints of the Primary Healthcare Workers. TJFMPC, 2018;12 (3): 162-170. DOI: 10.21763/tjfmpc.452425 


\section{INTRODUCTION}

Health communication is an important tool that contributes to the development of individual and societal health. In the field of health, only communication strategies can be used to raise awareness about a health problem and the solution of the problem. By using communication tools in health problems, it is possible to reach the results such as motivation of the individual towards the desired movement, consolidation of information and attitude related to the present positive health behavior, creation of demand for health services and an increase of service quality. It is also frequently used in the prevention of the diseases, in a production of the health services, in informing and training the individuals receiving health service about the processes related to treatment and the health care quality. ${ }^{1}$

Apart from the face-to-face interviews, one of the most widely addressed applications in health communication is telehealth practices. The use of communication technologies in the provision of the healthcare services is defined as telehealth. Telehealth services remove barriers to the healthcare services for patients, as well as increase communication of those living in remote areas from the health centers, students and local health personnel with the medical centers or medical specialists. ${ }^{2}$ Telehealth applications came to the fore in the world in the 1950s, and in Turkey in 2000s. The Republic of Turkey Ministry of Health prepared an action plan for this issue in 2006. In 2007, the teleradiology, telepathology and teleelectrocardiography services were established and in 2008, the number of hospitals covered by the application was increased. ${ }^{3}$ Telehealth applications are also common abroad. For example, if you have a health problem in Switzerland, you should call a consultancy agency first. From there, you will receive information and advice on what to do about your health problem. If necessary, you are directed to a doctor, hospital or therapist. ${ }^{4}$

In Turkey, the Ministry of Health has announced that it plans to reduce the number of unnecessary applications to the emergency services by giving a telephone consultancy (TC) watch to the family physicians by means of a structure similar to 112 command center. ${ }^{5}$ It is, of course, important to develop new models to reduce the burden of the emergency services. However, this will be more effective, if it is performed in the context of scientific studies and data. The aim of this research is to examine the perspectives and approaches of the primary health care workers in Turkey regarding directing the patients to the emergency service by providing them with TC service and to present some evaluation results in this respect.

\section{MATERIALS AND METHODS}

In this cross-sectional study, the universe of the research is composed of the doctors, family health employees (nurses, midwives etc) (FHE) working in the family practice in Turkey, assistants, and instructors in family physician department of the medical faculty. If it is necessary to define doctors; they are general practitioners working in the family health center, primary health care workers. FHE; they are working in the family health center and give preventive care as vaccination or contribute to patient education under the leadership of family physician. The assistants are doctors who are having specialist training in family medicine after graduating from medical school. Instructors in family physician department of medical faculty; these are trainers who provide training for assistants in family medicine specialty training. According to the data of the Ministry of Health in Turkey, there are 21696 family physicians and the same number of FHEs. ${ }^{6}$ When family physician assistants and instructors working in medical faculties and educational research hospitals are added, a target audience of about 50 thousand people in total can be mentioned. The number of samples that should be reached from the universe size table with the 95\% confidence interval and 0.03 sample error was calculated as $1045 .^{7}$ This number is our minimum target but we reached 1083 person. The online questionnaire technique was used to obtain the data. After the literature search, a questionnaire form was prepared, after it was applied to the pilot group of 40 people, the necessary arrangements were made and applied. The participants of the questionnaire were asked questions related to the TC by using the socio-demographic in data the first part and the 5likert scale in the second part. The target group was reached by random sampling method via e-mail, smartphone, and social media. Especially, the online questionnaire form shared in the email group of Family Physicians Federation (AHEF) and Turkey Associations of Family Physicians (TAHUD) and had tried to reach the target audience. Ethically, the participants were informed about the aims of the study and they were asked if they would like to volunteer for participation. They were also informed that they could withdraw from the study at any time and that all information would be kept strictly confidential. All of the data were collected in March 2017 in a one-month period. The data obtained in the study were presented with frequency, percentage, mean \pm standard deviation (SD) and categorical variables, number and percentage (\%) using the SPSS 15.0 package program. The relations between the dependent and independent variables were examined with the cross tables $($ Chi-square $=\chi 2)$. The $p<0.05$ was considered 


\section{TГT Family Medicine and Primary Care}

significant in determining whether there was a statistically significant relationship between the variables.

\section{RESULTS}

1083 health professionals participated in our study. The mean age of the participants was $38.29 \pm 9.19$ (min:20, max:65) and the mean of the professional experience year was $14.17 \pm 8.99$ (min:1, max:37). Other socio-demographic characteristics have been presented in table 1 . To the question of "Which one of the following would you prefer if you have to make a choice for the purpose of communicating with your patients apart from a face-to-face interview and ensure them to get into contact with you?" $32.0 \% \quad(n=347)$ informed that they would prefer to provide consultancy by telephone and $24.3 \%(n=263)$ by personal internet site and $23.2 \%$ $(n=251)$ by video interview and $20.5 \%(n=222)$ by social media tools. The viewpoints of the health professionals regarding the TC have been summarized in table 2. Our study was participated by attendance from 73 provinces in Turkey. The 8 provinces without participation in the questionnaire were found out to be Bitlis, Kırşehir, Nevşehir, Gümüşhane, Tunceli, Bayburt, Iğdır and Kilis. The provinces participating in the questionnaire were shown in figure 1 with the percentages of the seven geographical regions in Turkey.

No statistically significant difference was determined by age, gender, years of professional experience and employing institution with the proposal of "I support the TC project". However, there is a statistically significant difference in terms of the profession; and it was found out that FHEs looked more positively at this project than the general practitioner and family medicine specialists (table 3). The total proportion of the health professionals supporting the project was found out to be as low as $17.4 \%$. No statistically significant difference was determined between ages, gender, years of professional experience and employing institution with the proposal of "TC may cause malpractice and complications". However, there was a statistically significant difference determined in terms of occupation and gender (table 3). According to FHEs, it was found out that the physicians think that TC may cause malpractice and complications more. Males were found out to believe that malpractice may become more common than females.

A statistically significant difference was determined between ages, gender, years of professional experience and employing institution with the proposal of "TC is a populist approach". However, no statistically significant difference was determined between the employing institutions. It was found out that those who were older (age>35 years), those who had more professional experience (professional experience> 15 years), the doctors and men other than the others thought that this is a populist approach (table 3). No statistically significant difference was determined between ages, gender, years of professional experience and employing institution with the proposal of "TC service reduces the intensity in the emergency service". However, in term of the profession, the statistical difference was found significant $p=023$. Compared with FHEs; it was determined that the physicians did not think TC would reduce urgent applications.

\section{DISCUSSION}

Access of especially the elderly patients, who live on their own in the regions away from the health centers, to the health services constitutes an important problem. For these reasons, the use of telehealth and telenursing services has gained importance in recent years. ${ }^{8}$ Improvement, especially in the management of chronic diseases, can be achieved by means of TC. The TC has been found out to be generally successful in increasing medication compliance in people with hypertension and cardiovascular disease, in applying healthy diets and establishing lifestyle changes. ${ }^{9}$ Especially in the field of psycho-oncology, the telephonebased cancer information programs are reported to provide many benefits to the cancer patients. Through the planned, well-organized telephone interviews it can be provided that the patients take their own responsibilities in treatment and care for controlling the side effects of their illnesses, participate in the decisions made during the period of treatment and care, and enhance their quality of life to improve their compliance with disease, treatment, and care. ${ }^{10}$ It has been determined that providing diabetes training by phone is effective in diabetic patients receiving TC service. ${ }^{11}$ Again, telephone nursing consultancy was provided for providing medicine compliance of the ulcerative colitis patients and it was determined that the patients' compliance with medicine use increased longer than expected in 6-month telephone interviews. $^{12}$ In the study called the effect of monitoring the patients applied hip prosthesis at home via telephone; it was stated that monitoring patient via telephone is effective in monitoring post-discharge patients applied hip prosthesis and it was suggested that it can be used in the other fields, too. ${ }^{13}$ The persons, who wanted nutrition and exercise consultancy, were given a computercontrolled TC for 6 months and at the end of the 6th month, the participants were asked to rate this consultation between 0-100; according to this scale, those who found the system useful scored $63.6 \%$ and those satisfied with the system scored $62.3 \% .^{14}$ In our study, $63.2 \%$ of the health professionals 
reported that the citizens would be satisfied with the proposal of "TC satisfies the citizens". The rate of direct proportion is normally expected between the patient satisfaction and populist approach thought, here we got an inverse proportion. It should not be those, who think that such a practice is a populist approach, is $86.0 \%$. While a forgotten that the patient satisfaction shall not medically have the same meaning with the correct approach.

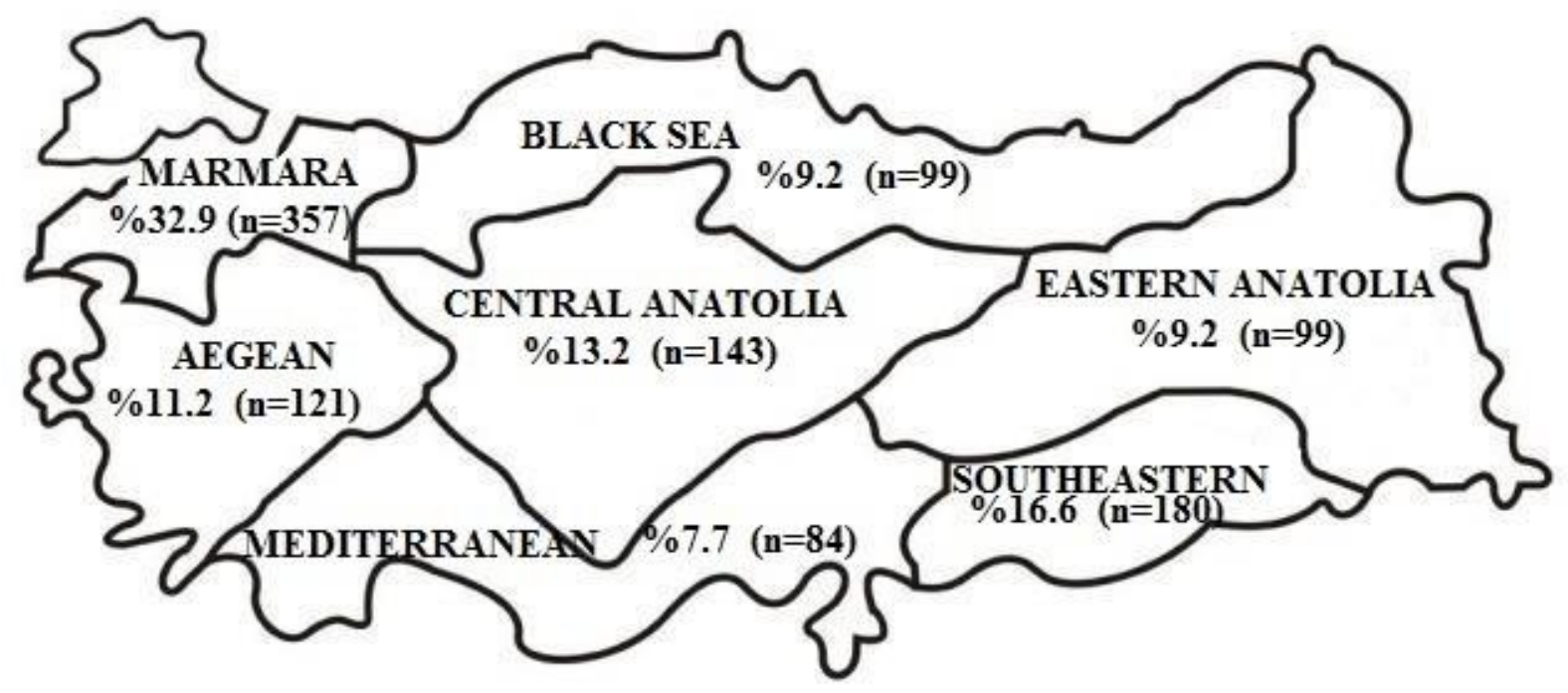

Figure 1. The number of persons participating in the study and their percentages per region

\begin{tabular}{|c|c|c|c|}
\hline & & $\begin{array}{c}\text { Number } \\
(\mathbf{n})\end{array}$ & $\begin{array}{c}\text { Percentage } \\
(\%)\end{array}$ \\
\hline \multirow{5}{*}{ Employing organization } & Family Health Center & 928 & 85.6 \\
\hline & Public Health Center & 54 & 5.0 \\
\hline & Education Research Hospital & 53 & 4.9 \\
\hline & University Hospital & 42 & 3.9 \\
\hline & Other & 6 & 0.6 \\
\hline \multirow{5}{*}{ Profession } & Midwife & 152 & 14.0 \\
\hline & Nurse & 108 & 10.0 \\
\hline & General Practitioner & 635 & 58.7 \\
\hline & Family Physician Specialist & 168 & 15.5 \\
\hline & Other & 20 & 1.8 \\
\hline \multirow{3}{*}{ State of education } & High School & 46 & 4.2 \\
\hline & University & 220 & 20.4 \\
\hline & Post Graduate - PhD & 817 & 75.4 \\
\hline \multirow{2}{*}{ Gender } & Female & 568 & 52.4 \\
\hline & Male & 515 & 47.6 \\
\hline \multirow{4}{*}{ Marital status } & Married & 826 & 76.3 \\
\hline & Bachelor & 224 & 20.7 \\
\hline & Widow & 7 & 0.6 \\
\hline & Divorced & 26 & 2.4 \\
\hline Total & & 1083 & 100 \\
\hline
\end{tabular}


Table 2. Responses of participants to the questions related to tele-consultancy

\begin{tabular}{|c|c|c|c|}
\hline & & $\begin{array}{c}\text { Number } \\
(\mathbf{n})\end{array}$ & $\begin{array}{c}\text { Percentage } \\
(\%)\end{array}$ \\
\hline \multirow{5}{*}{$\begin{array}{l}\text { Providing TC service reduces intensity in the } \\
\text { emergency service }\end{array}$} & Certainly I do not agree & 660 & 60.9 \\
\hline & I do not agree & 227 & 21.0 \\
\hline & I partially agree & 126 & 11.6 \\
\hline & I agree & 50 & 4.6 \\
\hline & Certainly I agree & 20 & 1.8 \\
\hline \multirow{5}{*}{ I support tc project } & Certainly I do not agree & 677 & 62.5 \\
\hline & I do not agree & 218 & 20.1 \\
\hline & I partially agree & 130 & 12.0 \\
\hline & I agree & 39 & 3.6 \\
\hline & Certainly I agree & 19 & 1.8 \\
\hline \multirow{5}{*}{ TC may cause malpractice and complications } & Certainly I do not agree & 24 & 2.2 \\
\hline & I do not agree & 25 & 2.3 \\
\hline & I partially agree & 107 & 9.9 \\
\hline & I agree & 256 & 23.6 \\
\hline & Certainly I agree & 671 & 62.0 \\
\hline \multirow{5}{*}{ TC satisfies the citizens } & Certainly I do not agree & 202 & 18.7 \\
\hline & I do not agree & 196 & 18.1 \\
\hline & I partially agree & 310 & 28.6 \\
\hline & I agree & 244 & 22.5 \\
\hline & Certainly I agree & 131 & 12.1 \\
\hline \multirow{5}{*}{ TC service is a populist approach } & Certainly I do not agree & 57 & 5.3 \\
\hline & I do not agree & 94 & 8.7 \\
\hline & I partially agree & 133 & 12.3 \\
\hline & I agree & 280 & 25.9 \\
\hline & Certainly I agree & 519 & 47.8 \\
\hline \multirow{5}{*}{$\begin{array}{l}\text { It would be more suitable to use "facebook, } \\
\text { twitter, whatsapp" and similar social media } \\
\text { tools for consultancy }\end{array}$} & Certainly I do not agree & 496 & 45.8 \\
\hline & I do not agree & 294 & 27.1 \\
\hline & I partially agree & 198 & 18.3 \\
\hline & I agree & 63 & 5.8 \\
\hline & Certainly I agree & 32 & 3.0 \\
\hline \multirow{5}{*}{$\begin{array}{l}\text { It would be more suitable to provide the } \\
\text { patients with video consultancy by using } \\
\text { social media and similar tools instead of TC }\end{array}$} & Certainly I do not agree & 487 & 45.0 \\
\hline & I do not agree & 289 & 26.7 \\
\hline & I partially agree & 173 & 16.0 \\
\hline & I agree & 94 & 8.7 \\
\hline & Certainly I agree & 40 & 3.7 \\
\hline Total & & 1083 & 100 \\
\hline
\end{tabular}




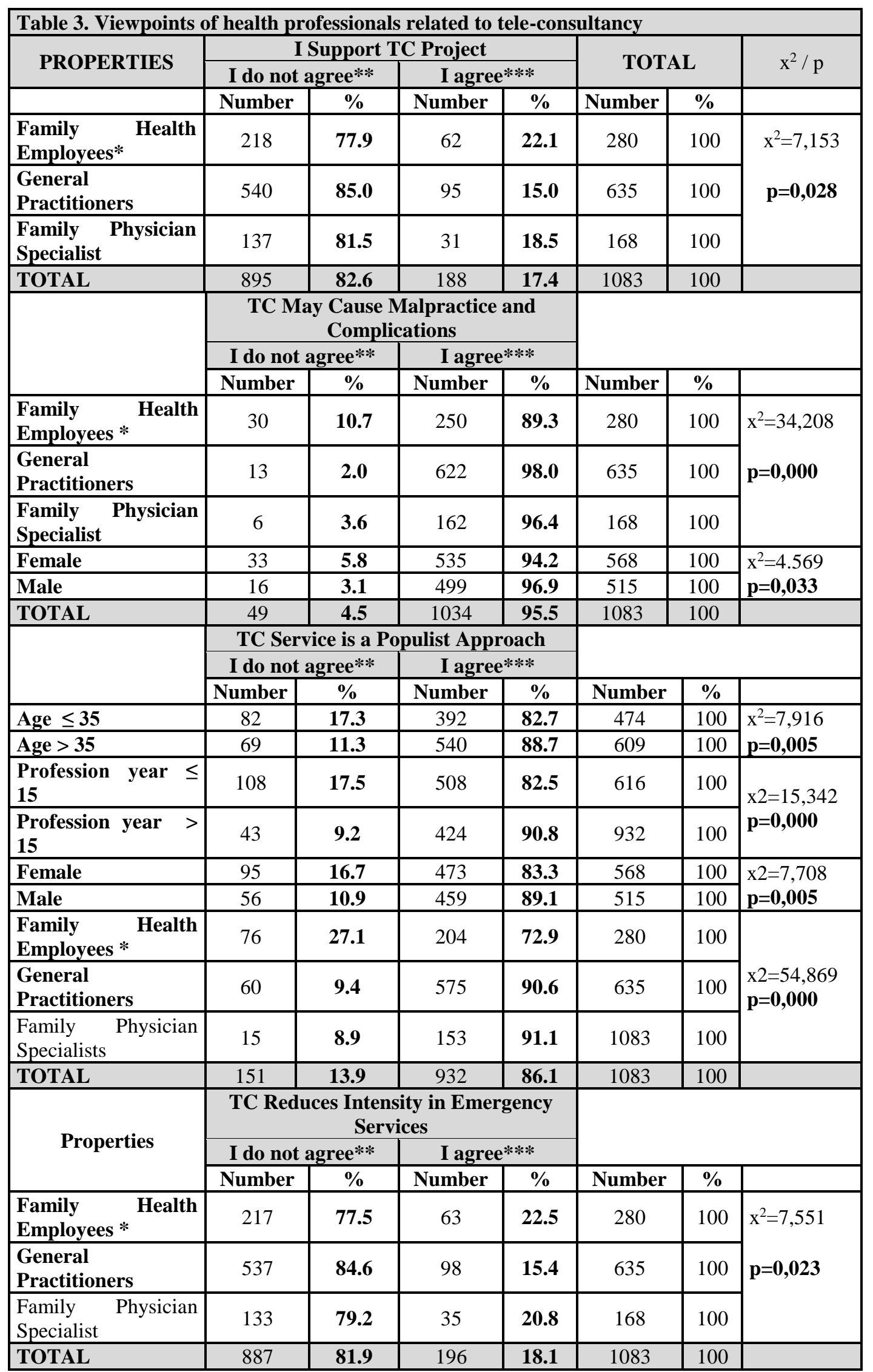

*The line creating the significant difference.

** I do not agree $=$ Certainly I do not agree + I do not agree (Please look at the Table 2) 
*** I agree $=$ I partially agree + I agree + Certainly I agree (Please look at the Table 2)

The telehealth practices are usually provided by nurses in the primary health care in the developed countries. Especially the nurses specialized in the field enables the individual to identify the health problem and direct him/her to the necessary resources in teletriage practice. The station, which is set up within the scope of a telehomecare, has a video conferencing unit connected to a regular telephone line. The patients provide the necessary home monitoring equipment (such as blood pressure monitor, oxygen saturation meter, glycemic monitoring device). ${ }^{15}$ Thus, telenursing services are a cost-effective method since they reduce the hospitalization rate and the length of hospital stay. By means of telenursing, continuity in care, improvement of care quality and patient satisfaction, cost reduction, performance evaluation, documentation and establishment of clinical guidance are provided. ${ }^{2,16,17}$

All of the above literature surveys reveal that TC can be used effectively, particularly in the follow-up of chronic diseases, in the education of the patients and caregivers, in the regulation of maintenance treatment, in monitoring after discharge from hospital and in the consolidation of lifestyle changes. Benefits of TC applications can be enlisted as improvement of continuity of care, improvement of quality of care, cost reduction and increase of satisfaction, performance evaluation, being reachable and easy to apply, documentation and establishment of clinical guidance, reducing the application to emergency service/hospital and hospitalization rate and the length of hospital stay, providing support for the patient and his/her family, improvement of communication, shortening the waiting duration, ensuring access to other health professionals, facilitating training, and provision of readily available information that can help eliminate healthcare needs. ${ }^{18}$

However, there are also studies showing the opposite. In a randomized controlled survey in Spain, it was found out that TC did not reduce emergency service applications and did not improve the patient's health in the chronic patients. ${ }^{19}$ On the other side, in another study, although the participants provided with TC services and having fertility problems stated that TC is supportive and useful in informing, it does not have any effect like the face-to-face consultation. ${ }^{20}$ It is stated that TC programs are very valuable and useful, as well as there are some evidences in some studies that the telephone does not give that confidence as face-toface communication does. ${ }^{18}$ When the subject matter is the management of emergency situations, there may be problems. In the study that we carried out, the health professionals do not approve the use of the telephone consultation in the management of emergency patients at a high rate of $80-90 \%$. In our study, $81.9 \%$ of the health professionals did not agree with the proposal of "TC reduces the intensity of the emergency service". The proportion of health professionals who support this project remains at a very low level of $17.4 \%$. More importantly, 95.5\% thought that they could cause malpractice and complications. In addition, in the study conducted in England, it was determined that the TC service provided by the family physicians and FHEs did not reduce the clinical contact duration of the patient and physician. ${ }^{21}$ In England, TC and triage are performed by the family physicians and nurses and are used to reduce the increased workload of the family practice. The research revealed that TC did not reduce the workload of the primary healthcare. ${ }^{22}$ All these studies support the concerns of those, who participated in our research. Researches that contradict this are very rare. In the literature review that we conducted, the study in which teletriage by the family physicians outside of working hours was found to be effective was a prospective observational study in Denmark, and in total $59.2 \%$ of the calls were terminated with telephone consultation. ${ }^{23}$

In the Netherlands, in the family practice system, the patients go to the family physicians taking an appointment for basic care. Those, who have doubts about whether or not their complaints are urgent, can consult their family physicians. Because those, who go directly to the hospital despite their complaints are not urgent, that is to say, those who do not comply with the referral chain, pay a personal risk share. Sometimes they may have to pay for all the costs themselves. Because of this reason, the family physicians provide the patients with TC service. Due to the fact that there is a referral chain, the patients are given appointments and ensured to receive a referral from the family physician. ${ }^{24}$ In Switzerland, specialist doctors are visited only upon the referral of the family physician. It is compulsory to make an appointment. Although it differs according to the agreement with the insurance company, the insurance does not cover this when the patient goes to the hospital without the referral. Even if you make an appointment, you may still have to pay if you do not report 24 hours in advance or if you do not go to your hospital appointment. Here, the costs are reduced by telephone service, and thus less premium payment is provided. ${ }^{4}$

It would be appropriate to plan the provision of telehealth services as a public service in connection with the other health service providing institutions within the overall health 
system. It is important that this service will be provided with supportive services so that it can be provided as required. For this reason, TC should be in the form of integration of home care services, health, and social services. There is a need for a legal arrangement that considers the current developments related to telephone service, covers all aspects of the service, and considers this service as a public service. In Turkey, the provision/receipt of telehealth service has not yet become widespread, and there is no model determined for how to do this. Infrastructure planning has not been carried out, and there are shortcomings of human power to provide these services. ${ }^{18}$

\section{CONCLUSION}

It should not be forgotten that we have a family practice application that is adapted to Turkey and has its own characteristics. In Turkey, there is no obligation for the referral chain and appointment system in the application of family practice. All services are free in the primary health care, and almost all of the health payments of the citizens in the second and third stage healthcare are under the state guarantee within the scope of General Health Insurance. Since access to health services is now very easy and free, unnecessary applications and congestions are sometimes inevitable. In Turkey, the drawbacks of using TC for patient triage and orientation to the emergency services are obvious. Moreover, it clear that TC is unlikely to reduce the unnecessary applications especially to the emergency services. In order to achieve this, it will be more effective to take deterrence measures such as premiums and contributions as in the foreign samples. However, TC can be effectively used to regulate chronic disease management, monitoring, and maintenance treatments by the family physicians. There is also a need for the legal arrangements to share and authorize the responsibility of the physician.

In the last few years, the family physicians in Turkey have been assigned to watch at night and weekends in the emergency services and this application was given up as it did not provide the expected productivity in practice. Later on, watch duties were given on the weekends in family health centers, this was also given up. Now, something new is being tried. However, in the field research that we carried out, the primary healthcare workers mostly oppose the TC issue. As the professional experience increase, this rate increases much more. Therefore, the field's pulse must be well analyzed by means of the scientific methods before a legal step is taken in this respect. The experience of the health professionals must be benefited. Applications that will result in a possible failure again should be avoided. Because since the health literacy is low in Turkey, TC will not satisfy the citizens and will not prevent the unnecessary applications to the emergency services. Even in countries abroad, where the levels of health literacy and education are high, TC is used in the follow-up of the chronic patients and is not used to reduce the emergency applications.

\section{Limitations of the Research}

The results of the research reflect the perceptions of the healthcare professionals participating in the questionnaire about the orientation of the patients to the emergency service by means of TC. The individuals, who did not participate in the questionnaire, gave up answering the questions by breaking short and do not actively use the online (mail and social media) technologies were left out. Therefore their views were not reached. The reliability and validity of the data obtained by the questionnaire are limited to the characteristics of this technique used in the data collection. The fact that the research data has been collected by the online questionnaire method and the lack of faceto-face interview technique is another limitation of the study.

\section{Acknowledgements}

We thank to all physicians and family practice colleagues, who supported our study, and to Dr. Mehtap ASLAN, the 2nd president of the board of directors of AHEF.

\section{REFERENCES}

1. Koçak A, Bulduklu Y. Health communication: The viewing motivations of health programs on television by elder people. Selçuk İletişim 2010:6(3);5-17.

2. Öz F. Bassis concepts in field of health. Nursing. 2nd edition, Ankara: Mattek typography, 2010:44-8.

3. Ertek S. Tele-Medicine and tele- health use in endocrinology practice. Acıbadem Üniversitesi Sağl1k Bilimleri Dergisi 2011;2:126-30.

4. Switzerland health guide. http://www.migesplus.ch/fileadmin/Publikation en/ tur_GWW_web_1_.pdf. Accessed 05.09.2017.

5. The minister of health Mr Akdağ participated in Anadolu Agency table of Editor Program. http://www.saglik.gov.tr/TR,13184/bakanakdag-aa-editor-masasina-konuk-oldu.html. Accessed 05.04.2017.

6. Republic of Turkey the Ministry of Health's Statistical yearbook of 2015. 143 http://www.saglikistatistikleri.gov.tr/dosyalar/S IY_2015.pdf Accessed: 05.10.2017. 


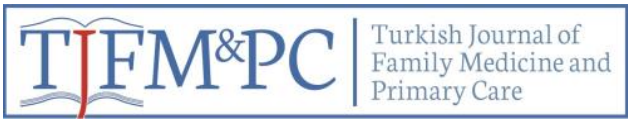

7. Yazıcıŏglu, Y. and Erdoğan, S. SPSS applied scientific research methods. Ankara: Detay publishing. 2004,50.

8. Pazar B, Taştan S, İyigün E. Roles of nurses in tele-health services. Bakırköy Tıp Dergisi 2015;11:1-4

9. Han HR, Kim J, Kim KB, Jeong S, Levine D, $\mathrm{Li} \mathrm{C}$ et al. Implementation and success of nurse telephone counseling in linguistically isolated Korean American patients with high blood pressure. Patient Educ Couns 2010;80:130-4.

10. Marcus AC, Garrett KM, Kulchak-Rahm A, Barnes D, Dortch W, Juno S. Telephone counseling in psychosocial oncology: a report from the Cancer Information and Counseling Line. Patient Educ Couns 2002;46:267-75.

11. Acemoğlu H, Ertem M, Bahçeci $M$ ve Tuzcu A. Levels of health care utilization in patients with type 2 diabetes mellitus. EAJM 2006;38:89-95.

12. Cook PF, Emiliozzi S, El-Hajj D, McCabe MM. Telephone nurse counseling form education adherence in ulcerative colitis: A preliminary study. Patient Educ Couns 2010;81:182-6.

13. Bilik Ö. Effects of observing hip prosthesis applied patients with telephone to the recovery. (Doctorate thesis) İzmir: Ege University Health Sciences Institute; 2006; 240.

14. Glanz K, Shigaki D, Farzanfar R, Pinto B, Kaplan B, Friedman RH. Participant reactions to a computerized telephone system for nutrition and exercise counseling. Patient Educ Couns 2003;49:157-63.

15. Lorentz MM. Tele-nursing and home healthcare the many facet of technology. Home Healthc Nurse 2008;26:237-43.

16. Valanis B, Tanner C, Moscato SR, Shapiro S, Izumi S, David $\mathrm{M}$ et al. A model for examining predictors of outcomes of telephone nursing advice. J Nurs Admin 2003;33:91-5.

17. Foels T, Terranova MD, Melzer SM. Afterhours telephone triage: reducing the financial burden- reply. Arch Pediatr Adolesc Med 2004:158-86.
18. Hintistan S, Cilingir D. A current approach in nursing practice: Telephone usage. Hemşirelikte Eğitim ve Araştırma Dergisi 2012;9(1):30-5.

19. Ortega MG, Badia JG, Kostov B, Martin CP. Randomized trial to reduce emergency visits or hospital admissions using telephone coaching to complex patients. Fam Pract 2017:34(2):219-26.

20. Bartlam B, McLeod J. Infertility counseling: the ISSUE experience of setting up a telephone counseling service. Patient Educ Couns 2000;41:313-21.

21. Holt TA, Fletcher E, Warren F, Richards S, Salisbury C. Telephone triage systems in UK general practice: analysis of consultation duration during the index day in a pragmatic randomized controlled trial. $\mathrm{Br} \mathrm{J}$ Gen Pract 2016;e214-17 DOI:10.3399/bjgp16X684001 e214 British

22. Campbell JL, Fletcher E, Britten N, Green C, Holt TA. Telephone triage for management of same-day consultation requests in general practice (the ESTEEM trial): a cluster randomized controlled trial and costconsequence analysis. Lancet 2014;384:185968, http://dx.doi.org/10.1016/S01406736(14)61058-8

23. Huibers L, Moth G, Carlsen AH, ChristensenMB, Vedsted P. Telephone triage by GPs in out-of-hours primary care in Denmark: a prospective observational study of efficiency and relevance. Br J Gen Pract 18 July 2016;bjgpsep-2016-66-650-huibers-fl-p. DOI:ttps://doi.org/10.3399/bjgp16X686545

24. Who new comer to Netherlands. https://www.government.nl/binaries/governme nt/documents/publications/2014/07/09/new-inthe-netherlands turkish/HR_92777_Brochure_Nieuw_in_Neder land_Niet+EU_Turks_v2.pdf. Accessed: 05.10.2017. 